\title{
Renal Abnormalities Associated with Mayer-Rokitansky-Küster-Hauser Syndrome
}

\author{
Emil Dorosiev, Galya Muzikadzhieva, Boris Mladenov, Ivan Stoev, Dimiter Velev \\ UMHATEM N.I. Pirogov, Sofia, Bulgaria
}

Corresponding author: Boris Mladenov, UMHATEM N.I. Pirogov, Sofia, Bulgaria; E-mail: boris_mladenov@abv.bg; Tel.: +359 884551093

Received: 3 Mar 2021 Accepted: 28 Apr 2021 Published: 31 Oct 2021

Citation: Dorosiev E, Muzikadzhieva G, Mladenov B, Stoev I, Velev D. Renal abnormalities associated with Mayer-Rokitansky-KüsterHauser syndrome. Folia Med (Plovdiv) 2021;63(5):815-8. doi: 10.3897/folmed.63.e63325.

\begin{abstract}
Mayer-Rokitansky-Küster-Hauser (MRKH) syndrome is a rare congenital disorder affecting female reproductive system (agenesis of uterus and upper part of vagina) alone (type 1), or associated with abnormalities of other organs and systems (type 2). We report a case of a 21-year-old woman diagnosed with MRKH due to primary amenorrhea during puberty and operated for formation of neovagina. She was admitted to the Department of Urology with abdominal pain and oligoanuria, where the physical examination and imaging studies revealed a malformation of the upper urinary tract: a solitary dystopia of kidney in the pelvis with stenosis of ureteropelvic junction and hydronephrosis. After initial desobstruction with a DJ stent, a pyeloplasty was performed. Females with primary amenorrhea are often delayed with the diagnosis of potential MRKH syndrome, and those diagnosed with the syndrome should undergo detailed examination to exclude concomitant urinary abnormalities.
\end{abstract}

\section{Keywords}

Anderson-Hynes pyeloplasty, hydronephrosis, kidney dystopia, MRKH syndrome, primary amenorrhea

\section{INTRODUCTION}

Mayer-Rokitansky-Küster-Hauser (MRKH) syndrome is a rare disorder in females, which is characterized by congenital agenesis of the uterus and the upper $2 / 3$ of the vagina. ${ }^{1}$ The frequency is approximately 1 in 4500 newborn girls and it affects predominantly the reproductive system. It was described first by Mayer ${ }^{2}$ in 1829 , with Rokitansky ${ }^{3}$ later publishing an article with similar malformations.

The anomalies of the reproductive tract are caused by incomplete development of the Müllerian duct ${ }^{4}$ which forms the uterus, fallopian tubes, cervix and upper part of the vagina during the embryonal development.

The kidneys develop from embryonic tissues similar to that of the Müllerian duct, which explains why the deviations in MRKH syndrome may also affect the upper urinary tract. ${ }^{5,6}$

When only reproductive organs are affected, this condition is called type $1 \mathrm{MRKH}$, while type $2 \mathrm{MRKH}$ syn- drome is characterised by additional anomalies in different organs and systems including renal abnormalities, skeletal, mainly vertebral abnormalities (Klippel-Feil syndrome: fusion of two or more cervical vertebrae), ribs malformation and/or spina bifida, auditory abnormalities, polydactyly, etc. ${ }^{7}$

Malformations of the upper urinary tract are present in $30 \%-40 \%$ of the cases. They consist mostly of unilateral renal agenesis $(23 \%-28 \%)$, ectopy of one or both kidneys (17\%), renal hypoplasia (4\%), horseshoe kidney, and hydronephrosis. ${ }^{8}$

There is a described case of bilateral renal agenesis, combined with absence of uterus and vagina in a fetus, aborted because of medical indications.

There is yet no conclusive evidence what part of females with an absent kidney may have the MRKH syndrome. 


\section{CASE REPORT}

A 21-year-old woman was admitted to our urological clinic because of pain in lower abdomen, mainly in the suprapubic area, asthenia, adynamia, nausea and vomiting, and oligoanuria for two days. She did not have a family history of hereditary diseases. She was diagnosed with MRKH syndrome at an age of 14 after primary amenorrhea - genital status: agenesis of uterus and upper 2/3 of the vagina, with normal ovaries. Her karyotype was normal (46XX). She underwent a gynecological operation: formation of neovagina 4 years ago.

Physical examination of the patient at admission showed worsened general condition, no fever, pale skin, and visible mucosa. Her blood pressure was 115/70 and she had normal cardiovascular and pulmonary findings. The abdomen was painful on palpation in the suprapubic area, where a palpable formation imitating globus vesicalis was identified. There were no signs for costovertebral angle tenderness. There was also kyphoscoliosis of the spine.

Blood laboratory samples revealed normal blood count and arterial blood gases and $\mathrm{pH}$ were within normal ranges. Potassium levels were normal, while creatinine and urea levels were significantly elevated (Table 1).

Ultrasound of abdomen showed an enlarged solitary kidney located in the pelvis, hyperechoic parenchyma and significantly dilated calyces and renal pelvis, and empty urinary bladder.

A retrograde pyelography ( $R P G)$ was performed and the solitary ectopic pelvic kidney was visualized right above the urinary bladder. The pyeloureteral junction was found to be stenotic. A DJ stent was placed in the ureter and the patient triggered adequate diuresis (Fig. 1).

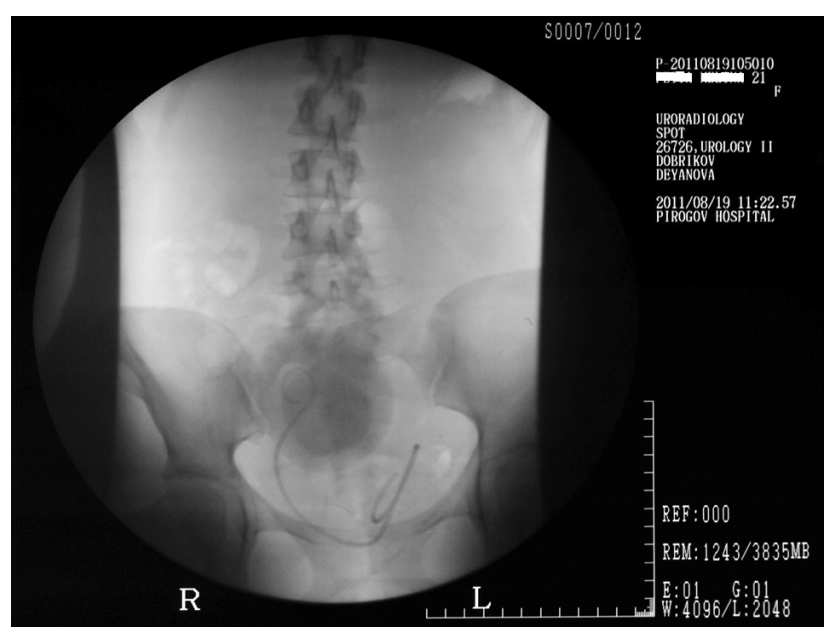

Figure 1. DJ placement in the ureter of the solitary ectopic pelvic kidney. RPG and retrograde cystography.

After normalization of creatinine clearance, a contrast CT with urography was performed. The findings were: ectopic pelvic solitary kidney, catheterized solitary ureter with a stenosis of pyeloureteral junction and agenesis of uterus (Fig. 2).

According to all radiological examinations, a surgery was suggested to the patient and performed 30 days after the first dehospitalization. An open reconstruction of the pyeloureteric junction a.m. Anderson-Hynes was done over a DJ stent. The postoperative period was uneventful and the DJ stent was removed 60 days later (Fig. 3 ).

Postoperative ultrasound and CT at 6 months revealed normal renal drainage and parenchyma; lab results were normal (Fig. 4).

Table 1. Laboratory findings at hospital admission

\begin{tabular}{lllllllll}
\hline Urea & Creatinine & $\mathbf{N a}$ & $\mathbf{K}$ & $\mathbf{C l}$ & $\mathbf{p H}$ & $\mathbf{B E}$ & $\mathbf{W B C}$ & $\mathbf{H b}$ \\
\hline $26.4 \mathrm{mmol} / \mathrm{l}$ & $921 \mathrm{umol} / \mathrm{l}$ & $138 \mathrm{mmol} / \mathrm{l}$ & $4.8 \mathrm{mmol} / \mathrm{l}$ & $96 \mathrm{mmol} / \mathrm{l}$ & 7.39 & -2.6 & $13.4 \mathrm{G} / \mathrm{l}$ & $121 \mathrm{~g} / \mathrm{l}$ \\
\hline
\end{tabular}
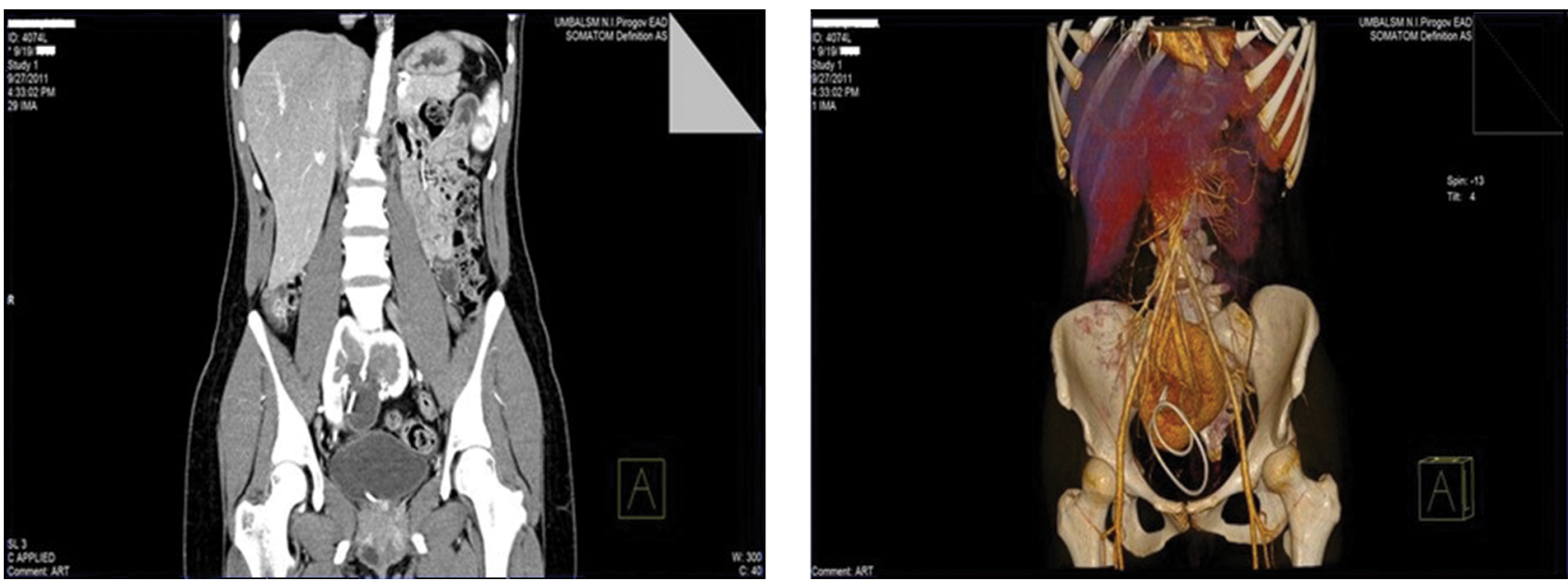

Figure 2. Images of CT scan with i.v. contrast - coronal view and reconstruction. 

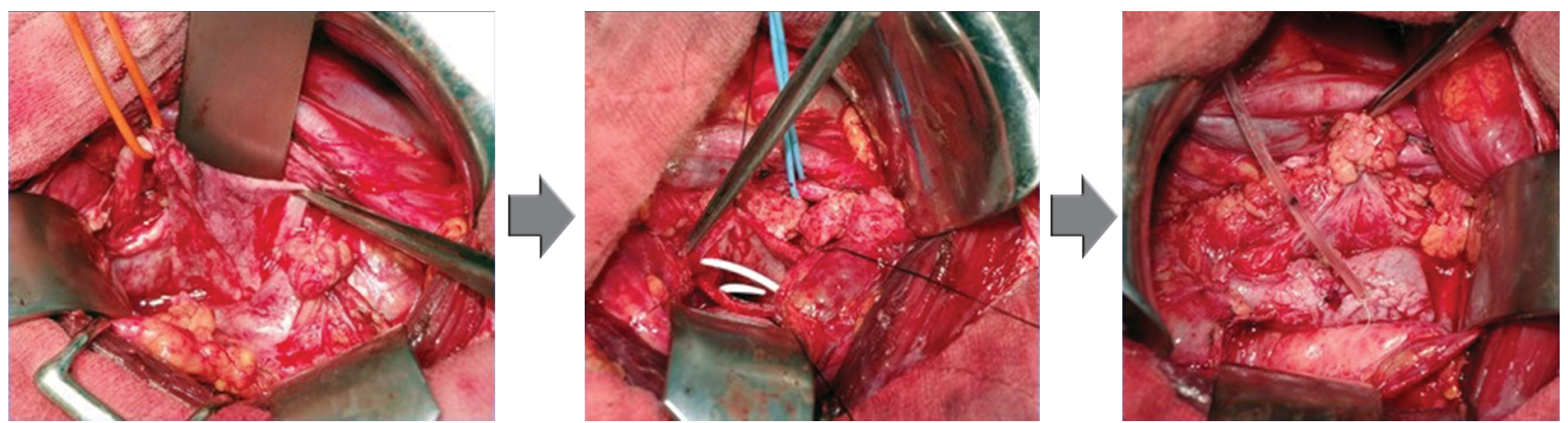

Figure 3. Anderson-Hynes pyeloplasty of the ureteropelvic junction of the ectopic pelvic kidney.

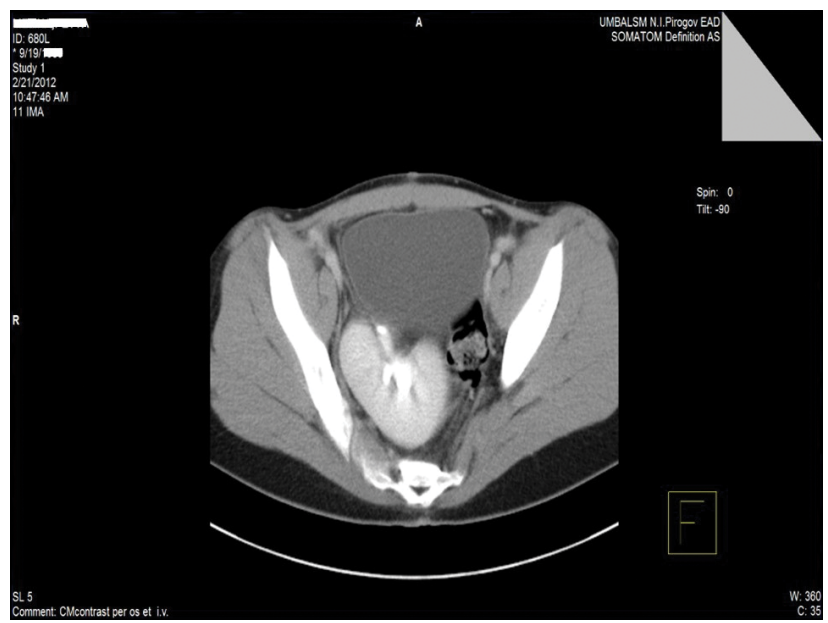

Figure 4. Postoperative CT scan after DJ stent removal.

\section{DISCUSSION}

MRKH syndrome is an extremely rare disorder in females mainly affecting the reproductive system. Patients have a normal karyotype and normal secondary sex characteristics. ${ }^{7}$ Our patient had a $46 \mathrm{XX}$ karyotype with normal development of her secondary sex characteristics during puberty: female type body hair and breast growth, normally looking external genitalia. The most common characteristic that makes patients and their families initiate a diagnostic process for revealing a MRKH syndrome is the primary amenorrhea during puberty, which was the indication in our case, too. This condition is the second most common cause for primary amenorrhea. ${ }^{8}$

The etiology of the syndrome is still unclear, previously it was considered that it may be caused by non-genetically relation factors like gestational diabetes, medications like thalidomide, teratogens, etc. ${ }^{9}$ Nowadays, it is known that the etiology of the condition is heterogeneous with autosomal dominant inheritance with varying degrees of penetrance and variable expression. ${ }^{7}$ There are reports of sporadic forms, like in our case, as well as for familial forms.

The isolated type 1 where only reproductive organs are involved is less common than type 2 with associated malformations. Our patient did have renal dystopia of a solitary kidney and scoliosis without impairment of hearing and cardiac defects. Renal malformations are present in $30-40 \%$ of cases, but according to our literature search, hydronephrosis of ectopic kidney in MRKH syndrome due to stenosis of pyeloureteral junction is extremely rare.

Our patient received a minimally invasive surgery for the vaginal agenesis by creating a neovagina in a gynecological clinic shortly after the MRKH syndrome was diagnosed, but no radiological examinations were performed to exclude associated malformations of other organs and systems. It is recommended that physicians perform early in-depth clinical evaluations and a variety of specialized tests, including specialized imaging techniques and laparoscopy if indicated. ${ }^{10}$

\section{CONCLUSIONS}

Our case report aimed at raising the awareness of the existing congenital gynecological anomalies which are often associated with malformations of the upper urinary tract. In cases of primary amenorrhea, actively searching and identifying anatomical and functional urological defects is important. Cases of hydronephrosis of a solitary ectopic kidney in patients with MRKH syndrome are extremely rare and they require an appropriate surgical correction. Long-term results depend on the correctly selected surgical methodology and technique of implementation.

\section{REFERENCES}

1. Wani MM, Mir SA. Chronic kidney disease in Mayer-RokitanskyKüster-Hauser syndrome. Indian J Nephrol 2010; 20(4):214-6.

2. Mayer CAJ. [About doubling of the uterus and its types, along with remarks about harelip and wolf's mouth.] Über Verdopplung des Uterus und ihre Arten, nebst Bemerkungen über Hasenscharte und Wolfsrachen. J Chir Augenheilkd 1829; 13:525-64 [Article in German].

3. Rokitansky C. [About the so-called doubling of the uterus.] Uber die sogenannten Verdopplungen des Uterus. Med Jahrb Ost Staat 1838; 26:39-46 [Article in German]. 
4. Kuster H. Uterus bipartitus solidus rudimentarius cum vagina solida. Z Gebuvtshilge Gynacol 1910; 67:692-718.

5. Hauser G, Schreiner W. Mayer-Rokitansky-Küster-Hauser Syndrome. Rudimentary solid bipartite uterus with solid vagina. Schweir Med Wochensch 1961; 91:381-4.

6. Fontana L, Gentilin B, Fedele L, et al. Genetics of Mayer-RokitanskyKüster-Hauser Syndrome. Clin Genet 2017; 91(2):233-46.

7. Oppelt P, Renner S, Kellermann A, et al. Clinical aspects of MayerRokitansky-Küster-Hauser syndrome: recommendations for clinical diagnosis and staging. Hum Reprod 2006; 21:792-7.

8. Shivakumar S, Surekha S. Mayer-Rokitansky-Küster-Hauser syndrome with unilateral pulmonary agenesis - a rarity indeed: radiologic review. BJR Case Rep 2016; 2(2):20150157.

9. Marsel K, Camborieux L. Programme de Recherches sur les aplasies Mulle riennes (PRAM), Guerrier D. Mayer-Rokitansky-Küster-Hauser Syndrome. Orphanet J Rare Dis 2007; 2:13.

10. Basile C, De Michele V. Renal abnormalities in Mayer-RokitanskyKüster-Hauser syndrome. J Nephrol 2001; 14(4):316-8.

\title{
Почечные аномалии, связанные с синдромом Майера-Рокитанского-Кустера-Хаузера
}

\author{
Емил Доросиев, Галя Музикаджиева, Борис Младенов, Иван Стоев, Димитр Велев \\ УМБАЛСМ „Н. И. Пирогов“, София, Болгария
}

Адрес для корреспонденции: Борис Младенов, УМБАЛСМ „Н. И. Пирогов“, София, Болгария; E-mail: boris_mladenov@abv.bg; Тел.: +359 884551093

Дата получения: 3 марта 2021 Дата приемки: 28 апреля 2021 Дата публикации: 31 октября 2021

Образец цитирования: Dorosiev E, Muzikadzhieva G, Mladenov B, Stoev I, Velev D. Renal abnormalities associated with MayerRokitansky-Küster-Hauser syndrome. Folia Med (Plovdiv) 2021;63(5):815-8. doi: 10.3897/folmed.63.e63325.

\section{Резюме}

Синдром Майера-Рокитанского-Кустера-Хаузера (МРКХ) - это редкое врождённое заболевание, поражающее женскую репродуктивную систему (агенез матки и верхней части влагалища) (тип 1) или связанное с аномалиями в других органах и системах (тип 2). Мы сообщаем о случае 21-летней женщины, у которой был диагностирован синдром МРКХ из-за первичной аменореи в период полового созревания, и она была прооперирована с целью формирования нового влагалища. Она была госпитализирована в отделение урологии с болями в животе и олигоанурией, где физикальное обследование и визуализация выявили порок развития верхних мочевыводящих путей: единичную почечную дистопию почечной лоханки со стенозом мочеточника и гидронефрозом. После первичной дефектации двойным Ј-стентом была выполнена пиелопластика. У женщин с первичной аменореей диагноз потенциального синдрома МРКХ часто откладывается, и тем, у кого диагностирован синдром, следует пройти подробное обследование, чтобы исключить сопутствующие аномалии мочеиспускания.

\section{Ключевые слова}

пиелопластика по методике Андерсена-Хайнса, гидронефроз, дистопия почек, синдром МРКХ, первичная аменорея 